\title{
CÂTEVA CAUZE ALE RUPTURII DINTRE BISERICĂ ȘI TINERI. SOLUȚII PENTRU O MAI BUNĂ COLABORARE
}

\author{
Ștefan-Gabriel Caraș
}

\begin{abstract}
Some Causes of the Breaking off between the Church and the Young People. Solutions for a Better Collaboration. In this study we emphasize the reality that the majority of practicing believers are elderly people, the young representing the minority in the perpetuation of the holy service. Considering this worrisome situation both for youth and the future of the Church, we identify in this study some of the causes that led to the alteration of the relationship between youth and Church, but in the same time we provide solutions for lifting the barrier between the analyzed parties. A cause for this rupture is the unawareness of God in a genuine way, namely what He wants from us, who Jesus Christ is, the reality that there is only one true God etc. As solutions to this unawareness we highlight the clear catecheses held in church, but also the religion classes. Another cause identified in our study for the distance between youth and the Church is the excessive materialism, the poverty of many young people, the desire of young people to became rich thus forgetting about God, but in the same time we also highlight the materialism of some clergy. As a minimal solution we consider the transparency in using the church's money, more modesty from the clergy, and the assistance of poor young who want to study. Another cause for the rupture of the two parties is atheism but mostly the religious indifferentism, especially towards the Church as an institution and not towards God Himself. Further we highlight some behavioral distortions of some clergy who do nothing but to widen the precipice between church and youth, but also the role of society, of family, mass media, which often fuels a separation of youth from Church.
\end{abstract}

Keywords: indifferentism, distortion, God, youth, materialism.

\section{Introducere}

Observăm în bisericile noastre că, cei mai mulți dintre cei prezenți la sfintele slujbe sunt persoane în vârstă, pensionari, iar tinerii cu greu se mai lasă cuprinși de fiorul dumnezeiesc al slujbelor, de mirosul de tămâie, preferând în schimb să își petreacă timpul în alte

* PhD Candidate, Faculty of Orthodox Theology, at University "1 Decembrie 1918", Alba Iulia, Romania. 
locuri în care sunt dominați de alte fioruri şi unde miresmele divine sunt absente. Acest adevăr zdrobitor îl constată atât clericii, cât și laicii, însă nu ne permitem să ne limităm la acest nivel de observare, ci trebuie să facem tot ceea ce ține de noi pentru a-i câștiga din punct de vedere spiritual și pe cei tineri. O biserică făă tineri activi este o biserică fără un viitor, în sensul de slăbire a acesteia, de marginalizare a acesteia în societate. Această tendință o întâlnim astăzi în anumite zone ale lumii, dar și la noi în țară, Biserica Ortodoxă Română este atacată mai ales de către cei tineri. Din păcate, Biserica Ortodoxă este ținta atacurilor la nivel European, nu doar ortodoxia, ci întreg creștinismul este martirizat, dacă ne aruncăm o privire la gruparea teroristă ISIS, grupare formată mai ales din tineri, unii dintre ei recrutați chiar din rândul creștinilor, ajungând să își sacrifice propria viață în numele unui dumnezeu fals, în numele unei ideologii bolnave.

În acestă lucrare vom încerca să evidențiem câteva aspecte care au determinat devieri în raportul dintre tineri şi Biserică, dar şi dintre tineri și ora de religie. Atât în raportul Biserică - tineri, cât și în raportul oră de religie - elev, neajunsuri sunt de ambele părți, însă Biserica are un rol primordial în a reduce nemulțumirile tinerilor (în unele cazuri întemeiate), atât față de Biserică, cât și față de ora de religie, sau mai bine spus față de profesorul de religie.

\section{Câteva cauze ale denaturării relațiilor dintre Biserică și tineri. Soluții pentru o mai bună colaborare}

Dacă privim lucrurile din perspectivă ideală, Biserica ar trebui să aibă o relație bună cu toate categoriile de vârstă, însă totuși nu este de multe ori aşa, de aceea subtitlul are în componența sa cuvântul denaturare, prin el am dorit să subliniem o anumită stare de anormalitate care trebuie vindecată. Sunt mai multe cauze care duc la îndepărtarea tinerilor de Biserică, dar atunci când vorbim de îndepărtare spunem implicit că, la un moment dat au fost apropiați de Biserică, iar această îndepărtare este cauzată de anumite nemulțumiri, frustrări ale tinerilor, neîmpliniri, neînțelegere a rolului Bisericii în societate, insesibilitate din partea unor clerici la problemele tinerilor, 
sentimentul inutilității tinerilor în Biserică, pierderea credinței, trecerea la alte credințe etc.

Sunt însă și cauze ale păstrării stării de neapropiere a tinerilor de Biserică. Pur și simplu aceștia păstrează distanța, văzând în Biserica o instituţie folositoare doar în anumite momente (Botez, Cununie, Înmormântare), iar mai nou observăm că nici în aceste momente unii nu mai apelează la Biserică. Vom încerca să reliefăm câteva cauze și să aducem la lumină posibile remedii ale acestor probleme vitale pentru Biserica noastră.

\section{Necunoașterea lui Dumnezeu de către tineri}

O cauză importantă a îndepărtării tânărului de Dumnezeu sau a neapropierii acestuia de Dumnezeu și implicit de Biserică (însă nu totdeauna) este necunoașterea lui Dumnezeu. O bună parte a tinerilor nu Îl cunosc pe Dumnezeu și aici nu ne referim la dogmele profunde ale teologiei, ci la ideile fundamentale pe care se bazează credința ortodoxă, adevăruri propovăduite de către Biserică. În câteva linii mari, putem afirma ceea ce unii tineri nu cunosc și anume: a) faptul că Dumnezeu este iubire (1 In. 4; 8, 11, 16, 17); b) că Dumnezeu este doar unul singur, cu alte cuvinte nu există două adevăruri (In. 17, 3; Efes. 4, 5); c) Iisus Hristos este Dumnezeu adevărat din Dumnezeu adevărat (Simbolul credinței); d) ce dorește acest Dumnezeu de la om sau invers, ce ar trebui să dorim noi de la Dumnezeu. Însă mai sunt și alte puncte în acest sens.

Dacă unii tineri nu îl cunosc pe Dumnezeu așa cum este El, este o lipsă a lor personală, un handicap al propriei lor persoane, însă în același timp, trebuie să recunoaștem că și Biserica prin slujitorii ei, preoții, dar și trimișii acesteia, profesorii de religie, au o vină. Voi sunteţi sarea pământului; dacă sarea se va strica, cu ce se va săra? De nimic nu mai e bună decât să fie aruncată afară şi călcată în picioare de oameni (Mt. 5, 13), sau Voi sunteţi lumina lumii (Mt. 5, 14), arată realitatea că și cei ce ar trebui să îl facă cunoscut pe Dumnezeu lumii, pot ajunge neputincioși din acest punct de vedere. Insă orice tânăr care dorește să Îl cunoască pe Dumnezeu așa cum este 
El, la modul autentic, ortodox, poate să facă aceasta, având un duhovnic, ascultând catehezele care se țin în biserică, îl poate cunoaște participând la conferințe cu teme spirituale, simpozioane, dar și printr-o trăire sănătoasă din punct de vedere spiritual, ceea ce presupune rugăciune, participare la Sfânta Liturghie, Spovedanie. Această trăire, care îl duce pe om, indiferent de vârstă, la viața veșnică, nu poate izvorî doar prin trăire mistică, ci și printr-o cunoaștere la nivelul rațiunii a lui Dumnezeu, atât cât este posibil (In. 17, 3).

$\mathrm{Cu}$ alte cuvinte, vina necunoașterii lui Dumnezeu se împarte, atât tinerii, cât și această sare a pământului (Mt. 5, 13) având propria vină. Totuși, fără să dorim să înclinăm balanța într-o parte sau alta, trebuie să fim onești până la capăt și să afirmăm clar și răspicat că orice tânăr, dacă dorește să-L cunoască pe Dumnezeu, o poate face, cel puțin la nivelul care să îi permită experimentarea unei credințe autentice. Doar cine nu dorește să vadă adevărul, doar acela nu îl cunoaște pe Dumnezeu, pentru că, vrând-nevrând, oriunde se duce omul, tânărul Îl întâlnește pe Dumnezeu ${ }^{1}$, iar o dată cunoscut, Dumnezeu nu poate fi uitat: Uitarea lui Dumnezeu este o uitare ontologică. E ca și cum ți-ai uita strămoșii, limba, sângele, propriul nume ${ }^{2}$. Tot în acest sens, afirmația că Dumnezeu nu trebuie căutat, El e de găsit ${ }^{3}$, arată că de Dumnezeu nu te poți feri, Îl poți afla oriunde te-ai duce, poți auzi de El oriunde te-ai afla, efortul omului fiind pus la încercare în sensul de receptare, cunoaștere autentică, aşa cum am mai spus.

Faptul că Dumnezeu este unic, neschimbabil, arată în consecință că există doar un Dumnezeu adevărat, o credință adevărată, autentică și de asemenea și doar o cale autentică ce duce la viața unde nu este durere, nici intristare, nici suspin ${ }^{4}$. Tinerii ignoră acest adevăr de multe ori, și nu numai ei, necunoscând sau nedorind să

\footnotetext{
'George Remete, Iisus Hristos, contemporanul necunoscut, în „Studii Teologice”, seria a II-a, anul LVI, nr. 3-4, iulie-decembrie, 2004, p. 15.

${ }^{2}$ Nicolae Turcan, Dumnezeul gândurilor mărunte, Cluj-Napoca, Edit. Limes, 2009, p. 67.

${ }^{3}$ Ibidem, p. 116.

${ }^{4}$ Molitfelnic, București, Edit. Institutului Biblic și de Misiune al Bisericii Ortodoxe Române, 2002, p. 225.
} 


\section{$15^{\text {th }}$ International Symposium on Science, Theology and Arts}

știe aceasta. Renunțarea la credința ortodoxă a unora, urmată de înrolarea în rândul sectelor, căsătoria cu cei de alte credințe, ceea ce nu este condamnabil, însă este de condamnat când în urma căsătoriei se observă o relativizare a credinței lor, mergând pe ideea că doar un Dumnezeu avem, unic, același în fiecare credință, toate acestea sunt începutul distrugerii propriei credinței, botezarea propriilor copii la alte credințe decât cea ortodoxă, este un risc al familiilor mixte din punct de vedere confesional, arătând o neînțelegere a lui Dumnezeu, o necunoaștere a Sa.

Ca și soluții la aceste probleme, susținem înmulțirea catehezelor clare, dese, susținute de către preoți, orele de religie bazate pe o programă realistă, aceste ore fiind dublate de un profesor competent, dar și înduhovnicit în același timp, un bun cunoscător al provocărilor la care sunt supuși tinerii astăzi.

$\mathrm{O}$ altă problema a tinerilor este necunoașterea celei de-a doua Persoane a Sfintei Treimi, Mântuitorul Iisus Hristos, a dogmelor Bisericii, în general. Unii nu îl văd pe Iisus Hristos ca pe Dumnezeu, pentru că nu înțeleg cum s-a putut Dumnezeu naște dintr-o femeie, ceea ce nu este de condamnat, până la urmă, Întruparea fiind o dogmă de neînțeles la modul deplin de niciun teolog oricât de strălucit ar fi, însă problema apare când tinerii îl separă pe Iisus Hristos de Dumnezeu, ceea ce este erezie. Această necunoaștere a lui Iisus Hristos, Acesta fiind perceput doar ca un Intemeietor religios venerabil $l^{5}$, duce la neînțelegerea propriei credințe, sau la o înțelegere greșită, fapt alarmant mai ales pentru tinerii care își construiesc crezul nu doar pe tradiție, ci și pe cunoaştere. Iar dacă nu îl înțelegi pe Hristos nu o înțelegi nici pe Maica Domnului. Astfel apar sectele sau se înmulțesc membrii acestor grupări religioase care știu să își educe adepții, aceștia având abilitatea a-i păstra pe tineri între rândurile lor. Recunoaștem astfel că, un sectar este mai bine informat, cunoaște mai bine Scriptura, chiar dacă o interpretează în interesul propriu, dar și cu scopul menținerii, al conservării propriei lor credințe. Observăm că, de multe ori tinerii evlavioși, dar necunoscători ai propriei credințe, ajung să cadă în

${ }^{5}$ George Remete, op. cit., p. 15. 
capcana sectelor, iar o dată ajunși acolo, încep să Îl cunoască greșit pe Dumnezeu, pe Iisus Hristos, ajung să o cunoască greşit pe Maica Domnului, pe sfinți și tot ceea ce ne separă pe noi de ei.

Ca și soluție la această provocare, constatăm că este nevoie de o mai multă și profundă cunoaștere a propriei credințe, a dreptei credințe, așa cum ne și îndeamnă de fapt și cuvântul Mântuitorului Iisus Hristos (In. 17, 3). Așadar nu putem vorbi doar de o cunoaștere duhovnicească, pietistă, bazată pe sentiment, evlavie, trăire interioară. Bineînțeles că efectul apropierii de Dumnezeu este îmbunătățirea vieții spirituale, sfințirea vieții, dar astăzi, când omul este pragmatic, curios, dorește să fie cât mai informat, este absolut necesar ca tânărul să își cunoască propria credință, să înțeleagă dogmele esențiale ale Bisericii și să nu se bazeze doar pe moștenirea spirituală primită de la părinți sau de la bunici. Pentru a contracara plecarea tinerilor din Biserica Ortodoxă, trebuie să îi educăm atât în cadrul slujbelor, dar și prin discuții clare, ori de câte ori avem ocazia, însă cu eleganță. Să punem mai mult preț pe educația tinerilor, tocmai pentru a-i forma ca și membrii activi ai Bisericii, dar și pentru a face lumină în mințile și în sufletele lor, pentru că Hristos, ajuns să fie cunoscut, aduce lumină omenirii, acest adevăr fiind exprimat de El Însuși când a spus clar $E u$ sunt Lumina; cel ce Îmi urmează Mie nu va umbla în intuneric, ci va avea lumina vieții $($ In. 8,12$)$.

O altă lipsă a tinerilor este faptul că îl cunosc pe Dumnezeu eronat, nu înțeleg că Dumnezeu de fapt este iubire nesfârșită. Este văzut Dumnezeu ca un polițist al lumii ${ }^{6}$, un Dumnezeu care pare foarte departe de om și este insensibil la durerile omenirii, războaie, sărăcie, catastrofe naturale, parcă tot mai dese, în fața cărora nimeni nu este imun. Toate aceste necazuri abătute asupra omului, tolerate, îngăduite de către Dumnezeu, îi fac pe unii să îl vadă pe Dumnezeu ca pe un tiran care îi ține pe oameni sub teroare. Însă nu este așa, iar acest adevăr îl observăm în istoria biblică, in istoria lumii. Există rău, pentru că de multe ori acest rău este provocat de către om, sau de multe ori este

${ }^{6}$ Teofil Tia, "Doctore, vindecă-te pe tine însuți” - Exigențele auto-terapiei psihopastorale, Alba-Iulia, Edit. Reîntregirea, 2003, p. 6. 


\section{$15^{\text {th }}$ International Symposium on Science, Theology and Arts}

îngăduit de Dumnezeu pentru a îndrepta erorile umane. Ca și răspuns la răul existent în lume, trebuie scos în evidență și binele existent, iar tinerii trebuie să vadă aceasta. Faptul că existăm, că există sănătate, tinerețe, viitor, pace, este un bine major de care tinerii trebuie să se bucure, iar în toate acestea să Îl vadă pe Dumnezeul cel adevărat care este bun și iubitor, iar dacă Îl văd pe Dumnezeu în tot ceea ce este bun, înseamnă că există toate șansele ca acești tineri să vadă în Biserică o fereastră spre Dumnezeu, un mijloc de a înmulți acest bine, dar și un mijloc de a trece mai ușor peste încercările vieții.

De asemenea, tinerii îl văd pe Dumnezeu prea aspru, un Dumnezeu care contabilizează păcatele lor ${ }^{7}$, de care nu te poți feri, prea obositor, prea rigid, un judecător sever. Iar dacă Dumnezeu este astfel perceput, de multe ori Biserica are grijă să adâncească acest crez al tinerilor. Canoanele neactualizate, rigiditatea unor clerici, neînțelegerea unor provocări contemporane și tratarea lor cu o prea mare severitate, au ca finalitate separarea tinerilor de Biserică. Însă Hristos, când a fost pe crucea Golgotei L-a mântuit pe tâlharul din dreapta Sa într-un timp scurt, fără multă vorbă, am putea spune că nici nu prea aveau timp prea mult să vorbească unul cu altul, erau pe moarte amândoi. Mai sunt și alte exemple care arată deschiderea enormă a Mântuitorului față de cei în păcat, putând să o dăm ca și exemplu pe Maria Magdalena, pe care o protejează de cei ce o criticau. Noi însă, suntem rigizi, iar pe aceasta linie de supercanonism am pierdut tinerii din Biserică, deorece păcatele societății sunt atât de agresive, iar bieții de ei nu mai reușesc să facă față $\breve{~}^{8}$ Aplicăm mirenilor canoane care sunt mai degrabă potrivite pentru călugări, îl cităm pe părintele Cleopa, mult și bine facem, dar pe lângă Ne vorbește părintele Cleopa, ar trebui să citim sau să ascultăm cuvântul hristic, când ne vorbește Domnul Iisus Hristos.

Pe lângă Dumnezeul rigid, greșit cunoscut de tânăr, acesta îl găsește și pe preotul rigid, mustrător, cel care îl ceartă pe tânăr legat de

\footnotetext{
${ }^{7}$ Ibidem, p. 14.

8 Emil Jurcan, Provocări religioase ale Europei contemporane, în „Altarul Reîntregirii”, serie nouă, anul XX, Nr. 3, septembrie-decembrie 2015, p. 14.
} 
vestimentație, de machiaj sau de batic, când vine vorba de femei, și aşa mai departe. E bine să existe o decență în biserică, o rânduială fără de care nu se poate, aceasta fiind cerută de Hristos pentru că Dumnezeu nu este un Dumnezeu al neorânduielii (I Cor. 14, 33), dar și o mai multă toleranță din partea preotului este absolut necesară.

\section{Materialismul accentuat, cauză a separării tinerilor de Biserică}

Referindu-ne la acest aspect, trebuie să îi împărțim pe tineri în două categorii. Cei care sunt săraci și cei mai înstăriți. Tinerii săraci sunt sclavii suferinței familiei lor, a lipsurilor, văd și trăiesc frustrările părinților lor, dar de multe ori simt și diferențierile care se produc în societate în funcție de starea materială, la școală, la serviciu, în instituțiile statului, aproape peste tot găsim aceste diferențieri dintre bogați și săraci. Unii dintre acești tineri neînstăriți nu își permit să meargă într-o vacanță, să își cumpere o locuință, iar toate acestea, cumulate cu lipsa locurilor de muncă, șomajul, ajung să degradeze tânărul, obligându-1 să se concentreze asupra unui stil de viață care are în centru banul.

Aflat pe acest drum, tânărul uită adeseori de Dumnezeu, care i se pare lui că este departe de el. Biserica pare câteodată imună la tot ceea ce înseamnă sărăcie, alteori este dependentă de lux, ceea ce îi face pe unii tineri să creadă că Biserica nu îi are în sfera ei de acțiune pe cei aflați în nevoi. Însă nu este așa, pentru că Biserica deține multe spații pentru săraci, cantine, centre de zi sau de noapte, școli, grădinițe și alte centre care au ca și punct central în activitatea lor și tânărul debusolat, sărac sau singur. $\mathrm{Cu}$ toate acestea sunt și clerici mai puțin sensibili la problemele reale ale tinerilor care se zbat în sărăcie, această sărăcie născând în sufletele lor dorința de a agonisi cât mai mult, cheltuindu-și în acest sens întreaga lor energie. Și dacă suntem cinstiți, nici măcar nu îi putem condamna pe tinerii care doresc să agonisească, iar în acest urcuș material uită de Dumnezeu. Este probabil o etapă în viața lor, viață care provoacă pe oricine la un moment dat şi din punct de vedere transcedental, pentru că omul nu este doar trup. 
$\mathrm{Cu}$ alte cuvinte, de Dumnezeu te lovești vrând-nevrând, practic, peste tot unde te duci, dai de El ... De aceea a crede că nu te interesează, că nu Îl atingi, nu-L cunoști sau Îl poți evita pe Iisus Hristos este totuna cu a crede că poți să te strecori prin viață netrăind .

Îl avem ca şi exemplu în acest sens pe Zaheu vameșul, materialist convins, căruia Hristos i-a schimbat viața. Bogățiile multe pe care le avea, multe dintre ele obținute nedrept, nu l-au mulțumit și a fost curios să Îl cunoască pe Hristos, a dorit să experimenteze alt tip de viață, de existență și a experimentat-o, Hristos ajutându-l, nepărăsindu-l pe acesta. Credem că va veni și timpul acestor tineri să îl caute pe Dumnezeu, iar în momentul în care îl vor găsi pe Acesta, viața lor se va schimba radical, iar preoții trebuie să îi ajute, să îi primească cu căldură, sa fie exemple de modestie, așa cum Hristos 1-a primit pe Zaheu, sau pe fiul cel risipitor, dar le-a fost și un exemplu de smerenie si de modestie, Exemplul Suprem.

Tinerii săraci sau tinerii bogați, și unii și alții, doresc să aibă cât mai mult, iar slujitorii Bisericii care merg tot pe acest drum materialist nu mai pot fi exemple de smerenie, de simplitate, modestie pentru tineri, această stare a ambelor părți provocând o falie de netrecut, o mare provocare pentru Biserică. Luxul unor slujitori ai Bisericii, pus față în față cu sărăcia multor tineri care abia supraviețuiesc, provoacă repulsie față de preoți și revoltă față de Biserica însăși. Versurile unei melodii mult îndrăgite de tineri redate în cele ce urmează : Mama ta muncește ca o sclavă / Să te duci la școală/ Măcar tu să o duci bine / În cartier, sărăcia se menține / Vezi copii numai piele și os / Garsonierele jegoase / Îți intorc stomacul pe dos ${ }^{10}$, arată clar sărăcia materială a societății, sărăcie care ajunsă la extrem duce și la o sărăcire spirituală. Aceste exemple sunt puține, marea majoritate a clericilor fiind ei înșiși modești, pot deveni modele de trăire spirituală, modele de demnitate umană, demnitate pe care nu ți-o oferă banul, ci virtuțile puse în

\footnotetext{
${ }^{9}$ George Remete, op. cit., p. 15.

${ }^{10}$ Teofil Tia, Pastorația tinerilor în era post-modernă. Tendințele socio-culturale ale lumii contemporane, Alba-Iulia, Edit. Reîntregirea, 2005, p. 20.
} 
lucrare, în slujba semenilor și spre lauda lui Dumnezeu. Din păcate însă, aceste puține exemple negative, sunt mediatizate excesiv, omul în general contabilizează mai mult răul decât binele și aşa se ajunge la condamnarea pe nedrept a întregului cin preoțesc, mai ales de cei cu o credință neconsolidată.

Astfel, unii tinerii devin membrii ai Bisericii doar cu numele, într-un registru de botezați sau cununați, în rest neavând tangență cu Biserica, ceea ce nu este bine pentru nimeni. Tinerii se pierd din punct de vedere spiritual, societatea se desacralizează, iar Biserica devine în mare parte a pensionarilor, ceea ce este o adevărată problemă care nu trebuie deloc neglijată. Mai mult decât atât, preoții ajung să fie văzuți ca slujbași ai banului, nu ai lui Dumnezeu, devin o categorie de oameni disprețuiți de mulți. Această realitate este exprimată prin cuvintele: neam trezit peste noapte că imităm sau ne luptăm ca să fim în top 300, că și Biserica noastră, prin unii reprezentanți, consideră că opulența înseamnă evlavie sau respect de cele sfinte ${ }^{11}$.

Însă, atunci când vorbim de banul Bisericii, atât cât este el, trebuie să observăm și invidia, răutatea, necunoașterea multora, care ajung să condamne întreaga Biserică sau întreaga preoțime din cauza puținilor clerici bogați, întreaga Biserică din cauza unei biserici și aici mă refer la Catedrala Mânturii Neamului (absolut necesară) care peste un număr de ani va deveni un punct important pe harta capitalei, pe harta României, pe harta Europei și atunci mulți se vor bucura de prezența ei, mult mai mulți, pentru că și astăzi când unii dintre credincioșii Biserici, critică acest consum de bani pentru construirea unei catedrale, observăm ca și mai mulți o apără, iar între apărători sunt și foarte mulți tineri.

Vedem reacția multora la clipul formației Taxi numit Despre smerenie, când un mesaj ostil Catedralei Mântuirii Neamului, s-a întors ca un boomerang, arătând credința multor tineri care înțeleg bine și limpede raportul dintre bogăție și semnificație, dintre manipulare și adevăr, ceea ce arată că, totuși, bogăția, rolul banului bine înțeles, până la urmă nu îl îndepărtează pe om, pe tânăr de biserică, însă în acest sens

${ }^{11}$ Emil Jurcan, op. cit., p. 15. 


\section{$15^{\text {th }}$ International Symposium on Science, Theology and Arts}

şi clerul are un rol determinant. Omul care vrea să înțeleagă și face eforturi în acet sens, înțelege rolul bisericii, fie ea mare sau mică, de lemn sau nu, pentru că în om există o sete fără margini, o nevoie de durată absolută și dorul după o desfătare fără margini ${ }^{12}$, pe care o găsim doar în biserică.

Ca și o remediu în această problemă ar fi o mai bună comunicare a preoților, o mai mare transparență în folosirea banului, modestia și bunul simț de asemenea, acolo unde ele lipsesc, iar acest comportament, consider că l-ar apropia pe tânăr de Biserică și implicit de preoți. Dar înainte de a trece la fapte, atât tânărul, cât și clericul insensibil la sărăcia altora, trebuie să își revină în sine ca și fiul cel risipitor, însă primul în această ecuație trebuie să fie preotul, tânărul putând fi adus de altcineva în sine, iar acela trebuie să fie preotul. Trebuie să avem capacitatea de a distinge între bine și rău, între viciu și virtute, dreptate și nedreptate ${ }^{13}$, asemenea fiului risipitor, care văzându-se golit de orice virtute, bogăție sufletească sau materială, văzând că dacă continuă tot pe acel drum va muri, s-a întors deplin la tatăl său, smerit. De această smerenie avem și noi nevoie, de o revenire în sine deplină, iar această stare interioară a omului va produce profunde schimbări în bine atât pentru tineri, cât și pentru Biserică.

\section{Ateismul și indiferentismul religios în rândul tinerilor}

Trebuie spus de la început că doar 1,1\% dintre români sunt atei, mai mult de jumătate dintre aceștia locuind în București ${ }^{14}$, deci vorbim de o minoritate clară, însă atunci când vorbim despre indiferentism religios, lucrurile stau cu totul și cu totul altfel, chiar dacă ne declarăm

\footnotetext{
${ }^{12}$ Christos Yannaras, Foamea și setea, București, Edit. Anastasia, 2000, p. 20.

${ }^{13}$ Text cules de pe coperta a doua a cărții scrisă de Andrei Plesu, Minima moraliaElemente pentru o etică a intervalului, ed. a II-a, București, Edit. Humanitas, 1994.

${ }^{14}$ http://www.rgnpress.ro/rgn 14/categorii/economic-social/18439-sondaj-inscopromanii-i-religia-popor-credicios-dar-i-superstiios-in-proporie-de-839-romanii-seconsider-persoane-religioase-doar-11-sunt-atei.html (accesat la data de 14.04.2016).
} 
un popor religios conform aceleiași cercetări de mai sus. Suntem membrii ai Bisericii, credem în Dumnezeu, Îl cunoaștem mai mult sau mai puțin, dar mulți dintre tineri sunt indiferenți atunci când vine vorba de Dumnezeu, de relația lor cu Biserica. Câți dintre tineri participă la slujbele Bisericii, câți se spovedesc regulat, câți au un duhovnic, câți postesc sau se roagă ?

Mai grav, observăm că nu se mai cunună la biserică unii dintre ei, unii preferă să fie incinerați, unii sunt în conflict cu ierarhia superioară bisericească, unii au devenit ostili propriei lor credinței. Însă, chiar dacă tinerii și nu numai ei, devin parcă tot mai insensibili din punct de vedere spiritual, constatăm cu durere că mulți dintre acești tineri sunt indiferenți nu față de Dumnezeu, ci sunt indiferenți în fața rigidității unor clerici, nu acceptă birocratizarea credinței, dar nici anumite denaturări de comportament ale unei mici părți din cler despre care am pomenit în rândurile de mai sus, iar pe altele le vom enunța în restul lucrării.

Chiar dacă acești tineri sunt foarte puțini, Biserica nu are voie să îi neglijeze. Iisus Hristos spune la un moment dat că, dacă o oaie se pierde, lasă cele 99 și o caută pe cea pierdută. Nu avem voie să-i părăsim pe cei credincioși, mai mult sau mai puțin practicanți, nici măcar pe atei, ci trebuie să urmăm exemplul lui Hristos. Trebuie să îi aducem la credință și pe cei atei, atât cat este posibil. Sunt și ei chemați la mântuire, iar Biserica trebuie să arate dragoste și față de ei. Vorbind despre atei, Papa Francisc a spus: Toți suntem copiii lui Dumnezeu, absolut toți! Iar Dumnezeu ne iubește, pe absolut toți ! ${ }^{15}$, chiar dacă Papa a completat că orice ateu se poate și mântui dacă face binele, ceea ce nu este în concordanță cu învățătura Bisericii Ortodoxe. Acești tineri atei au valoare atât spirituală cât și intelectuală, dar cu toate acestea, ateismul este drumul care duce la pierzanie pentru că Luciditatea fără credință este moarte cu ochii larg deschiși ${ }^{16}$, chiar dacă Suveranul

15 http://semneletimpului.ro/religie/papa-francisc-si-ateii-care-fac-binele-suntmantuiti.html (accesat la data de 15.04.2016).

${ }^{16}$ Nicolae Turcan, op. cit., p. 79. 
Pontif Francisc I, și-a exprimat punctul de vedere în privința ateilor la postul media Vatican Radio, spunând astfel:

Doar fă binele! Avem chipul lui Dumnezeu; El face bine, iar noi avem cu toții porunca aceasta în inima noastră: fă binele și nu răul. Toți. «Dar, Părinte, acesta nu e catolic! $\mathrm{Nu}$ poate face binele!» $\mathrm{Ba}$ da, poate! Trebuie!... Domnul ne-a răscumpărat pe toți, pe toți, cu sângele lui Christos: pe toți, nu doar pe catolici. Pe toată lumea! «Părinte, chiar și pe atei?» Chiar și pe atei! Pe toată lumea!... Trebuie să ne întâlnim unii cu alții prin facerea binelui. «Dar eu nu cred, Părinte, eu sunt ateu!» Dar fă binele: ne vom întâlni acolo! ${ }^{17}$.

Noi nu împărtășim acest punct de vedere, însă putem învăța ceva din cuvintele Papei Francisc I. Și aceștia trebuie luați în considerare, chiar dacă sunt doar $1,1 \%$ pe teritoriul Romîniei. Totuși considerăm că omul în esența sa, în adâncul sufletului său, nu poate fi ateu, sau cel puțin nu unul convins. Şi persoana care s-a declarat atee în discuția avută cu Papa, nu o putem considera $100 \%$ atee, pentru că, dacă era așa, probabil nu ar fi dorit să vorbească cu episcopul Romei. Eu cred că există inlăuntrul fiecăruia dintre noi o nevoie de viață, de sens și de implinire care nu poate fi satisfăcută decât de Izvorul vieții noastre, de Cel ce ne-a dat viață și ne cheamă la comuniunea cu El ${ }^{18}$.

Faptul că cineva te încurajează și nu te condamnă înseamnă mult pentru oricine, mai ales pentru tinerii care au nevoie ca cineva să îi ghideze, să îi înțeleagă, să vorbească cu ei, în acest sens avându-1 model pe Iisus Hristos care a vorbit cu mari păcătoși biblici, Zaheu, Maria Magdalena, cu păgânii, cu slabii lumii, și pentru toți a avut un cuvânt bun, mai ales când cei ce se apropiau de El aveau intenții bune.

$17 \mathrm{http}: / /$ semneletimpului.ro/religie/papa-francisc-si-ateii-care-fac-binele-suntmantuiti.html (accesat la data de 15.04.2016).

${ }_{18}$ Interviu cu Sebastian Moldovan de la Facultatea de Teologie „Sfântul Andrei Şaguna" din Sibiu, realizat de Ruxandra Atanasiu în revista "Familia Ortodoxă", nr. 10 (33), octombrie, 2011, p. 50. 


\section{Sentimentul inutilității tinerilor în raport cu Biserica}

De multe ori, oamenii apropiați de Biserică sunt cei în vârstă, cântărețul, clopotarul, consilierii parohiali, sunt oameni trecuți de prima tinerețe. Constatăm că Biserica este administrată de pensionari chiar dacă sunt tot mai mulți preoți tineri. Această stare o găsim mai ales la sate, unde pe lângă faptul că vârstnicii participă mai mult la slujbele oficiate în biserică și situația demografică este alarmantă. Însă ce facem cu tinerii care mai sunt, pentru că și ei sunt credincioși și ar putea ajuta Biserica cel puțin la fel de bine ca și unul pensionar. Tinerii simt că nu este loc și pentru ei în biserică, simt că biserica este pentru cei în vârstă.

Aici putem vorbi și de indiferentism pe de o parte, dar pe de altă parte putem vorbi și de respingerea tinerilor de către biserică, la polul opus, cântăreți bătrâni care nu doresc să aibă în preajma lor la strană vreun tânăr pe care să îl învețe rânduielile slujbelor, consilieri bisericești care nu lasă loc și altor credincioși din anumite motive, interese materiale, mândrie sau fală. În acest sens, ar trebui ca tinerii să aibă câteva locuri asigurate în Consiliul Parohial, de drept, iar la strană să fie pe lângă cântărețul titular al bisericii și tineri care să învețe de la acesta, astfel asigurându-se și o continuitate în cântarea liturgică.

Organizarea de pelerinaje cu tinerii, responsabilizarea acestora, programele de voluntariat, acordarea unor mici ajutoare celor nevoiași, sunt câteva elemente care ar naște în inima tânărului sentimentul că Biserica are nevoie de ei, că și ei sunt parte a Bisericii și încă una foarte importantă.

Iisus Hristos, atunci când și-a ales apostolii, și-a ales și tineri, ştiut find faptul că Ioan, fiul lui Zevedeu, a fost un adolescent când a fost chemat la apostolat. Maica Domnului însăși a fost o adolescentă când a fost vizitată de Sfântul Arhanghel Gavriil și i-a binevestit că îl va naște pe Fiul lui Dumnezeu. Deci tinerii trebuie sa fie mai mult respectați, apreciați și integrați în bunul mers al Bisericii. Un tânăr clopotar, un tânăr care să îl însoțească pe preot la binecuvântarea caselor de Bobotează sau la alte evenimente, naște in inima lor sentimentul că sunt apreciați, iar prin faptul că îi responsabilizăm îi și 
ajutăm să se dezvolte și din punct de vedere emoțional, relaţional, elemente importante în dezvoltarea umană.

\section{Denaturarea, în anumite cazuri a slujirii preoțești, o cauză a îndepărtării tinerilor de Biserică}

Am pomenit mai sus principala problema care duce la îndepărtarea tinerilor de Biserică, și anume luxul anumitor clerici. Dar pe lângă acest păcat al unor fețe bisericești, sfidător de multe ori, mai există anumite deraieri comportamentale ale membrilor bisericii, însă trebuie să punctăm și slăbiciunile sau păcatele unor tineri. Așa cum am spus, unii tineri şi unii clerici s-au îndepărtat de ceea ce este normal, iar din cauza acestora Biserica este catalogată ca neprietenoasă, denaturată de către tineri, iar la rândul ei și Biserica acuză că tinerii s-au denaturat. Adevăr există de ambele părți, dorim să vedem ce deranjează și ce se poate face, să gasim soluții pentru a apropia cele două părți.

Considerăm că este o denaturare ca preotul să certe permanent de la amvom și nu numai. Chiar dacă îl avem model pe Hristos care nu a cruțat păcatul, a certat și chiar a pus mâna pe bici, totuși vedem că în activitatea Sa misionară a prevalat bunătatea, smerenia, toleranța, înțelegerea. A avut milă față de flămânzi, față de copii, i-a păsat de suferința părinților pentru propriii copii, nu a trecut cu vederea pe nimeni. Critica permanentă, dublată de pretenția de a strânge bani mereu pentru diverse lucrări, chiar dacă ele sunt bune, îl transformă pe preot într-un neprieten și într-un contabil sau administrator. Tocmai din acest punct de vedere oamenii îl văd pe preot mai mult un administrator şi chiar ei înşiși se simt aşa, în acest sens mai mulți preoți fiind dispuși să se lepede chiar și pentru o perioadă de timp, preferând un loc de primar. Un preot care dorește să candideze pentru postul de primar al unui oraș, spune așa:

Voi candida, dar în calitate de cetăţean al municipiului (...), nu ca preot, şi mă voi suspenda în această perioadă. Vreau o altfel de politică la (...), în interesul cetăţeanului, nu în interesul ştim noi cui se face în acest moment. M-am implicat în fenomenul cultural, dar şi economia acestui 
oraş are nevoie de altceva. Sunt necesare locuri de muncă şi de o viziune $\operatorname{adaptată}^{19}$.

Faptul că un preot candidează din partea unui partid politic renunțând la preoție, atât în perioada campaniei electorale, dar și în timpul posibilului mandat de primar în cazul în care va fi votat, este o denaturare pe care oamenii nu o aprobă și cu atât mai mult tinerii care oricum sunt dezgustați de clasa politică și stau de multe ori departe de ea. Cred că este uşor de intuit cum privesc tinerii acest caz de preot politician sau care dorește să fie politician și nu mai dorește să fie preot cât timp este politician.

Sfântul Sinod al Bisericii Ortodoxe Române aprobă candidatura unui cleric, însă independent politic pentru un post de consilier județean sau local, nu aprobă candidatura unui cleric înregimentat politic și pentru un post de primar. Dorința de putere administrativă este mai mare decât dorința de a-L sluji pe Dumnezeu, exact ca în cazul celor doi apostoli, Iacov și Ioan, fii lui Zevedeu, care își doreau funcții importante însă s-au ales cu un refuz din partea Mântuitorului Iisus Hristos (Mc. 10, 43-45). Tot Mântuitorul spune la un moment dat Daţi deci Cezarului cele ce sunt ale Cezarului şi lui Dumnezeu cele ce sunt ale lui Dumnezeu (Mt. 22, 21), parcă dorind să spună că Dumnezeu si Cezarul sunt total separați și oricum nu putem sluji la doi dumnezei, aceasta fiind spusă tot de Domnul Hristos (Lc. 16, 13).

Conform hotărârii Sfântului Sinod al Bisericii Ortodoxe Române, un preot poate îndeplini misiunea laică de consilier local sau județean fără probleme, pentru că aceste demnități publice nu necesită renunțarea la slujirea sacerdotală, pe când demnitatea de primar presupune renunțarea la preoție în timpul exercitării mandatului.

$\mathrm{O}$ altă denaturare a slujirii preoțești este comportamentul abuziv. Și în primul caz este tot un abuz, preotul abuzând de calitatea sa sacerdotală mai mult decât de calitățile sale de bun administrator, însă unii preoți abuzează de calitatea lor atât în biserică cât și în afara

19 http://adevarul.ro/news/politica/popi-politica-sinodului-pacatele-candidatilorsutane-lasa-dumnezeu-fotolii-consilieri-primari-

$1 \_571501995 \mathrm{ab} 6550 \mathrm{cb} 81 \mathrm{e} 628 \mathrm{f} / \mathrm{index} \cdot \mathrm{html}$ (accesat la data de 18.04.2016). 


\section{$15^{\text {th }}$ International Symposium on Science, Theology and Arts}

ei, atât în timpul slujirii preoțeşti cât și în timpul lor liber ceea ce din nou nu face decât să îndepărteze mai ales pe tânăr de Biserică. De ce? Pentru că tânărul este mult mai critic la abuzuri în general decât cei care au trăit mai mult în comunism, și pe de altă parte, el însuși se simte abuzat de multe ori de către mai marii societății, iar când observă că acest abuz există chiar și în rândul clericilor, îl demoralizează puternic. El dorește să vadă în preot un exemplu moral și îl privește pe acesta ca pe un ultim reper într-o lume imorală și de foarte multe ori nedreaptă.

Să dăm câteva exemple de comportament abuziv. Din cauza unui zel prea puternic, din dorința de a fi credincioșii ochi și urechi doar la slujirea liturgică, ceea ce este ideal, unii preoți nu suportă plânsul copiilor și chiar îi poftesc pe aceștia în afara bisericii împreună cu mama sau tatăl copilului. Este și de prost gust, dar și contrar cuvintelor Mântuitorului Hristos care spune clar: Lăsaţi copiii să vină la Mine şi nu-i opriţi, căci a unora ca aceştia este împărăţia lui Dumnezeu (Mc. 10, 14). Hristos nu a fost deranjat când patru bărbaţi au desfăcut acoperișul unei case și au lăsat în mijlocul camerei unde se afla un bolnav pe o targă, nu a fost deranjat de strigătele mamei care avea o fată demonizată, de cei zece leproși, ba din contră, a știut să vorbească cu fiecare în parte. Observăm că pe Hristos nu 1-a deranjat zgomotul, ci dimpotrivă a provocat zgomot, având ca și exemplu dialogul cu femeia samarineancă, în timp ce ucenicii Săi îi spuneau acesteia să tacă (Mt. 15, 21-28).

Unii preoți nu acceptă femeile fără batic în biserică, unele mănăstiri de asemenea, ceea ce este de înțeles, însă nu este de înțeles când nu te acceptă în mănăstire dacă nu achiți o taxă de intrare, iar răceala cu care ești primit sau mai degrabă cu care nu eşti primit ca şi pelerin la anumite mănăstiri este de asemenea o problemă care trebuie observată și eliminată, pentru că obștile monahale trebuie să fie și sunt locuri sfinte unde pelerinii vin în primul rând pentru a primi 
binecuvântare, locuri unde călugării îi ascultă pe pelerini şi îi sfătuiesc, oferă îndrumare pastorală $\breve{2}^{20}$.

Trebuie specificat că aceste denaturări sunt excepții, însă și aceste excepții duc la îndepărtarea tinerilor de Biserica lui Hristos și de slujitorii ei.

\section{Ruptura duhovnicească dintre tânăr și profesorul de religie}

O altă cauză a rupturii dintre Biserică și tineri sunt orele de religie prost făcute. Chiar dacă profesorul de religie trebuie să colaboreze cu preotul local și viceversa, în practică de multe ori se întâmplă ca profesorul să se rezume strict la partea teoretică, la ceea ce predă la catedră și atât. Relația cu preotul se face defectuos, în acest caz preotul fiind cel care trebuie să preia inițiativa și să determine profesorul să păstreze o legătură reală cu Biserica, scopul acestei discipline fiind și acela de modelare duhovnicească a elevilor pe lângă partea informativă. Aducerea elevilor în grup la Biserică, participarea la concursuri școlare a elevilor, pot imprima in inimile copiilor sentimentul apartenenței lor la Biserica lui Hristos, ceea ce înseamnă enorm. Moralitatea, verticalitatea, optimismul, sunt câteva calități morale strict necesare tânărului, preotul și aici având un rol determinant, în sensul că are capacitatea mai pregnantă de a apropia tinerii de tot ceea ce înseamnă moral, frumos.

Atunci când profesorul este el însuși rupt de biserică și își vede materia pe care o predă doar ca o sursă de venit, lucrurile stau prost pentru că elevii simt starea duhovnicească a profesorului lor, care ar trebui să le fie exemplu. Ținuta, comportamentul acestuia în clasă, relația sa cu părinții copiilor, sunt foarte importante, acestea putând

\footnotetext{
${ }^{20}$ Irineu, Arhiepiscop al Alba Iuliei, Mănăstirea, oază de învioarare spirituală și mesajul ei către lume prin servire și proexistență, în "The missionary ethos of the church in post-modernity-Ethosul misionar al Bisericii in post-modernitate", vol. 1, Supplement of "Altarul Reîntregirii” Journal, Alba-Iulia, Edit. Reîntregirea, 2015, p. 9-10.
} 
influența atât pozitiv cât și negativ copiii, tinerii. Acest adevăr îl exprimă Sfântul Paisie Aghioritul astfel:

Mare lucru este un învățător corect, mai ales în zilele noastre! Copiii sunt casete neînregistrate, care se vor umple fie cu cântece murdare, fie cu muzică bizantină. Lucrarea învățătorului este sfântă .... dă societății oameni renăscuți și astfel ea se face mai bună ${ }^{21}$.

Oricât de bun ar fi profesorul, copiii au nevoie și de îndrumare spirituală, de aceea, elevii, tinerii, trebuie să fie apropiați de biserică, binomul Școală-Biserică având un rol extrem de important în dezvoltarea educațională și morală a tinerilor.

De multe ori ne plângem că elevii nu mai sunt ascultători, sunt dezinteresați, de necontrolat chiar, însă problema considerăm că se află la părinții copiilor, dar și la educator, acest adevăr fiind afirmat de către Jean-Marie Petitclerc, preot și educator, astfel: Copiii noștri nu se nasc diferiți de cei de altădată, sunt pur și simplu mai puţin educați ${ }^{22}$. Unii profesori și-au pierdut zelul, asta dacă l-au avut vreodată, se axează pe programă fără să intre și în sufletul copilului, ceea ce este esențial, aceasta fiind afirmată și de Sebastian Moldovan, de la Facultatea de Teologie Andrei Șaguna din Sibiu care consideră că

principala problemă sunt educatorii, nu cei educaţi. De obicei dăm vina pe tineri, dar adevărata problemă sunt adulții, [care, crescuți mulți dintre ei în comunism n.n.] un sistem al minciunii, iar generațiile tinere de atunci, fiind în căutarea autenticității, sorbeau cu nesaț ceea ce părea a fi autenticitate- idealuri de emancipare, de bunăstare și de prestigiu, urmărite însă cu mijloace infracționale, cu șmecheria și turnătoria, cam asta-i moștenirea pe care societatea adulților de azi o lasă copiilor ${ }^{23}$.

${ }^{21}$ Paisie Aghioritul, $\mathrm{Cu}$ durere şi cu dragoste despre omul contemporan, Edit. Evanghelismos, 2003, în „Familia Ortodoxă”, nr. 10 (33), octombrie, 2011, p. 2.

22 Jean Sevillia, Corectitudinea morală: căutăm cu disperare valori, trad. de Alina-Daniela Marinescu, Paul Marinescu, București, Edit. Humanitas, 2009, p. 31.

${ }^{23}$ Interviu cu Sebastian Moldovan, realizat de Ruxandra Atanasiu în revista "Familia Ortodoxa" ..., p. 49. 
Puțina educație, educaţia fără angrenarea credinței în Dumnezeu, sau proasta educație, provoacă falii între tineri și Biserică, rupturi pe care cu greu le mai putem reface, de aceea este nevoie de buni educatori și de buni preoți, dar nu despărțiți, ci uniți, astfel unitatea și integritatea membrilor Bisericii este consolidată.

\section{Concluzii}

Omul fiind creat după chipul lui Dumnezeu are nevoie de Creatorul său, aspiră după Acesta, însă aceasta aspirație spre divinitate este sufocată câteodată de cauzele enunțate în lucrare, omul de multe ori rămânând singur în acest drum către Dumnezeu. Tocmai de aceea, Hristos a lăsat Biserica Sa pe pământ, aceasta are datoria să lupte și să elibereze acest drum pe care trebuie să pășim încă din tinerețile noastre.

Iar acest drum se eliberează de spini, de capcane, dacă ne înarmăm cu armele Bisericii, slujbele ei, preoții, trimișii Bisericii în școli, profesorii, cu toții având menirea să lucrăm la mântuirea și la formarea tinerilor. Sunt încercări mari, unele venite din exterior, altele din interiorul Bisericii, dar împreună vom putea parcurge acest drum avându-L ca și sprijin total pe Iisus Hristos care a spus În lume veţi avea necazuri, dar îndrăzniţi, Eu am biruit lumea (In. 16, 33). 


\section{Bibliografie}

1. *** Revista Familia Ortodoxă , nr. 10 (33), octombrie, 2011.

2. Molitfelnic, București, Edit. Institutului Biblic și de Misiune al Bisericii Ortodoxe Române, 2002.

3. Irineu, Arhiepiscop al Alba Iuliei, Mănăstirea, oază de învioarare spirituală, și mesajul ei către lume prin servire si proexistență, în The missionary ethos of the church in post-modernity-Ethosul misionar al Bisericii in post-modernitate , vol. 1, Supplement of "Altarul Reîntregirii Journal, Alba-Iulia, Edit. Reîntregirea, 2015.

4. Emil Jurcan, Emil, Provocări religioase ale Europei contemporane, în Altarul Reîntregirii, serie nouă, anul XX, Nr. 3, septembrie-decembrie 2015.

5. Pleșu, Andrei, Minima moralia - Elemente pentru o etică a intervalului, Ed. a doua, București, Edit. Humanitas, 1994.

6. Remete, George, Iisus Hristos, contemporanul necunoscut, în Studii Teologice, seria a II-a, anul LVI, nr. 3-4, iulie-decembrie, 2004.

7. Sevillia, Jean, Corectitudinea morală: căutăm cu disperare valori, trad. de Alina-Daniela Marinescu, Paul Marinescu, București, Edit. Humanitas, 2009.

8. Tia, Teofil, Doctore, vindecă-te pe tine însuți - Exigențele auto-terapiei psiho-pastorale, Alba-Iulia, Edit. Reintregirea, 2003.

9. Idem, Pastorația tinerilor în era post-modernă; Tendințele socioculturale ale lumii contemporane, Alba-Iulia, Edit. Reîntregirea, 2005.

10. Turcan, Nicolae, Dumnezeul gândurilor mărunte, Cluj-Napoca, Edit. Limes, 2009.

11. Yannaras, Christos, Foamea și setea, București, Edit. Anastasia, 2000.

\section{Resurse web:}

1. http://www.rgnpress.ro/rgn 14/categorii/economic-social/18439-sondajinscop-romanii-i-religia-popor-credicios-dar-i-superstiios-in-proporie-de839-romanii-se-consider-persoane-religioase-doar-11-sunt-atei. html.

2. http://semneletimpului.ro/religie/papa-francisc-si-ateii-care-fac-binelesunt-mantuiti.html.

3. http://adevarul.ro/news/politica/popi-politica-sinodului-pacatelecandidatilor-sutane-lasa-dumnezeu-fotolii-consilieri-primari1 571501995ab6550cb81e628f/index.html. 